\title{
$30^{\circ}$ 이내의 얼굴돌림을 보인 영아눈떨림환자에서 Modified Anderson 술식
}

\section{Modified Anderson Procedure in Infantile Nystagmus with Face Turn within 30 Degrees}

\author{
양상철 ${ }^{1} \cdot$ 전혜신 ${ }^{1,2} \cdot$ 최희영 ${ }^{1,2}$ \\ Sang Cheol Yang, $\mathrm{MD}^{1}$, Hyeshin Jeon, $\mathrm{MD}^{1,2}$, Hee Young Choi, MD, $\mathrm{PhD}^{1,2}$ \\ 부산대학교 의과대학 안과학교실 ${ }^{1}$ 부산대학교병원 의생명연구원 ${ }^{2}$ \\ Department of Ophthalmology, Pusan National University School of Medicine ${ }^{l}$, Yangsan, Korea \\ Biomedical Research Institute, Pusan National University Hospital', Busan, Korea
}

\begin{abstract}
Purpose: To evaluate the efficacy of modified Anderson procedure in infantile nystagmus with face turn less than 30 degrees. Methods: This study was a retrospective review of the medical records of 13 consecutive patients who underwent a modified Anderson procedure for abnormal head position in infantile nystagmus at Pusan National University hospital from February 2002 to March 2017. We compared best-corrected visual acuity (logarithm of minimal angle of resolution, logMAR), refraction, degree of face turn, ocular motility, and angle of deviation preoperatively and at 1 week postoperatively, 6 months postoperatively, and the final visit. Recession of the yoke rectus muscles responsible for the slow phase of nystagmus was performed, depending on the direction of face turn; the medial rectus muscle of the eye to which the head was turned was recessed $10 \mathrm{~mm}$, whereas the lateral rectus muscle of the contralateral eye was recessed $12 \mathrm{~mm}$.

Results: The mean age of the patients was 8.9 (2-25) years, and the mean follow-up period after surgery was 51.3 (6-183) months. Twelve patients $(92.3 \%)$ had no residual head posture or $<10^{\circ}$ at 6 months postoperatively, and three patients $(23.1 \%)$ achieved this outcome with an additional operation. The mean degrees of face turn were $22.30^{\circ}$ before surgery and $3.85^{\circ}$ postoperatively $(p=0.001)$. Best-corrected visual acuity (logMAR) was 0.41 in the better eye and 0.50 in the worse eye before surgery; this improved to 0.34 and 0.45 at 6 months postoperatively ( $p=0.068$ and $p=0.228$, respectively). Despite the large recessions involved, only one patient showed mild limitation of abduction after surgery.
\end{abstract}

Conclusions: The modified Anderson procedure may be effective for correcting abnormal head position in infantile nystagmus with face turn less than 30 degrees; patients were not overcorrected.

J Korean Ophthalmol Soc 2019;60(6):569-574

Keywords: Abnormal head position, Modified Anderson procedure, Nystagmus

- Received: 2019. 1. 10.

- Revised: 2019. 2. 16.

- Accepted: 2019. 5. 17.

- Address reprint requests to Hee Young Choi, MD, PhD Department of Ophthalmology, Pusan National University

Hospital, \#179 Gudeok-ro, Seo-gu, Busan 49241, Korea

Tel: 82-51-240-7324, Fax: 82-51-240-7341

E-mail: hychoi@pusan.ac.kr

* Conflicts of Interest: The authors have no conflicts to disclose.
영아눈떨림은 생후 수개월 이내에 나타나는 안구운동의 장애로 다른 신경학적, 안과적 이상이 배제되어야 하고 불 수의적, 규칙적이며 시선의 방향에 따라 눈떨림의 정도가 변화한다. 눈떨림의 정도가 최소가 되는 시선의 방향을 정 지점이라고 하며 정지 구역에서 시력이 가장 좋다. ${ }^{1}$ 정지 구역이 제 1 안위와 일치하지 않는 경우 정지점을 전방으로 향하도록 머리를 돌려 얼굴돌림, 머리기울임, 턱올림, 턱내 림 등의 이상두위를 취하게 된다. 이러한 이상두위를 동반 
한 눈떨림에 있어 정지 구역이 정면을 향하도록 하는 수술 은 이상두위교정을 통한 미용적 문제 해결뿐만 아니라 정 면주시 시 눈떨림을 최소화시켜 시력을 호전시키는 것을 목표로 한다.

1953년 Kestenbaum ${ }^{2}$ 에 의해 양안의 수평직근 중 저속기 에 해당하는 동향근 후전술을 실시하고 대항근은 절제술을 하는 술식이 소개되었다. Parks ${ }^{3}$ 는 각 수평직근에 서로 다 른 정도의 절제량, 후전량을 적용하는 Modified Kestanbaum 술식을 소개하였으며, 이후 얼굴돌림의 정도가 큰 경우에 수술하더라도 부족교정이 되거나 재발되는 소견이 있어 수 술량을 크게 하는 Augemented Modified Kestenbaum 술식 등이 소개되었다. ${ }^{4,5}$ Anderson $^{6}$ 은 저속기와 급속기의 움직 임이 중요함을 설명하였는데, 저속기는 중심와가 주시점으 로부터 천천히 벗어나는 단계이며 고속기는 중심와를 다시 주시점으로 위치시키기 위한 교정 운동이다. 이런 저속기 는 주로 직근의 과도한 활동으로 일어난다고 생각하여 저 속기에 관여하는 2 개의 수평직근을 후전시키는 술식을 소 개하였다. 절제술을 포함하지 않으므로 보다 손쉽고, 두 근 육만 후전하므로 상대적으로 수술 시간이 짧다. 적은 량의 이상두위를 교정했던 기존의 Anderson 술식에 비해 Modified Anderson 술식은 후전량을 증량시켜 이상두위의 정도가 큰 경우에도 효과를 나타내는 술식이다. 후전량이 $10-14 \mathrm{~mm}$ 로 많아 안구운동제한을 일으킬 수 있다는 우려가 있지만 실제로 안구운동제한을 보인 경우는 적었고, 두 눈의 수평 네 개의 직근을 모두 후전하는 방법과 비교하여 이상두위 개선 정도는 유사하다는 보고가 있었다. ${ }^{7}$ 본 연구는 영아눈 떨림으로 인한 $30^{\circ}$ 이내의 얼굴돌림 환자에서 Modified Anderson 술식의 효과를 알아보고자 하였다.

\section{대상과 방법}

2002년 6월부터 2017년 3월까지 부산대학교병원 안과에 서 영아눈떨림으로 진단받고 이상두위교정을 위해 Modified Anderson 술식을 시행받고 6 개월 이상 추적관찰한 환자 13 명 을 대상으로 의무기록을 후향적으로 분석하였다. 본 연구 는 부산대학교병원 생명윤리의원회의 심사를 받고 승인받 았다(IRB 1812-008-074).

성별, 수술 당시 나이, 수술 전후 최대교정시력, 초진 시 필요한 경우 조절마비 굴절검사를 시행하였고 이상두위 정 도, 안구운동 및 사시각을 분석하였다. 수술 전후 시력 측 정 시에 환자가 시력을 최대화하기 위한 보상 작용인 이상 두위를 취하는 것을 제지하지 않았으므로 수술 전에는 이 상두위에서의 시력 측정을 하였으며, 수술 후에는 이상두 위가 사라진 환자는 정면에서 시력 측정을 하였고 이상두
위가 남은 환자는 이상두위에서 시력을 측정하였다. 진료 시에 영아눈떨림이 의심되는 환자들은 $6 \mathrm{~m}$ 거리의 목표물 을 주시하게 하여 고개돌림 방향 및 정도에 따라 눈떨림의 방향, 진폭, 빈도와 속도를 임상적으로 측정하였고 눈떨림 의 강도가 가장 적어지는 정지 구역을 확인하였다. 그리고 이상두위 정도 측정은 동일한 검사자가 환자가 $6 \mathrm{~m}$ 거리의 목표물을 주시하였을 때 얼굴돌림, 고개기울임, 턱올림, 턱 내림의 각도를 정형외과 각도기(orthopedic goniometer)로 측정하였다.

수술은 $30^{\circ}$ 이하의 얼굴돌림환자에서 Modified Anderson 술식에 근거하여 얼굴돌림의 방향에 따라 저속기에 해당하 는 동향근인 2 개의 수평직근을 후전시키는 두 개의 수평근 후전술을 시행하였고, 얼굴돌림 정도에 따라 수술량을 정 하였다. 사시가 동반되어 있다면 사시교정에 필요한 만큼 수술량을 가감하여 시행하였다. 모든 수술은 동일한 수술 자에 의해서 시행되었으며, 수술 전 얼굴돌림이 $15-25^{\circ}$ 였던 환자에게는 얼굴돌림의 방향과 같은 눈의 내직근 $10 \mathrm{~mm}$ 후전술, 반대눈 외직근 $12 \mathrm{~mm}$ 후전술로 총 $22 \mathrm{~mm}$ 의 수술 량을 적용하였고, $30^{\circ}$ 의 얼굴돌림이 있던 3 명에게는 $10 \%$ 증량된 수술량인 23-24 mm로 수술하였다. $30^{\circ}$ 의 얼굴돌림 에 내사시가 동반된 환자 1 명은 원래의 수술량에 사시교정 에 필요한 만큼의 수술량을 더하여 시행하였다. 수술 후에 과교정이나 부족교정으로 이상두위가 재발한 경우나 턱의 위치 이상이 발생한 경우, 그리고 사시가 발생한 경우에는 추가 수술을 시행하였다.

수술의 결과는 수술 전후 1 주, 6 개월, 최종 내원 시 얼굴 돌림 정도와 최대교정시력을 비교하여 평가하였다. 최대교 정시력의 경우 소아의 시력 발달을 배제하고 Modified Anderson 술식으로 인한 시력호전 효과를 확인하기 위해 최종 내원 시의 시력은 제외하고, 수술 전과 수술 후 6 개월 의 시력을 비교하였다. 수술의 성공 기준은 수술 후 $10^{\circ}$ 이 내로 얼굴돌림이 교정되어 미용적 또는 기능적으로 문제가 되지 않는 경우로 하였고, 실패는 수술 이후 경과관찰 중에 $10^{\circ}$ 이상의 얼굴돌림을 보인 경우와 과교정이나 부족교정 으로 추가 수술을 받은 경우로 하였다.

통계분석에는 수술 전후의 비교를 위해 통계 프로그램 SPSS (SPSS version 18.0 for windows, IBM Corp., Armonk, $\mathrm{NY}, \mathrm{USA}$ )를 이용하였으며, 수술 전과 수술 후의 시력과 이상두위 정도 비교는 Wilcoxon signed rank test를 사용하 였다. 통계학적 유의성의 기준은 $p<0.05$ 로 하였다.

\section{결 과}

총 13 명의 환자 중에 10 명은 남자, 3 명은 여자였으며 수 
술 당시 환자들의 평균 연령은 $8.9 \pm 6.49$ 세(2-25)였다. 사 시가 동반되었던 경우는 5 명이었으며 이 중 1 명은 $14 \mathrm{PD}$ 의 내사시, 4명은 8-12 PD의 외사시가 있었다. 눈떨림의 분 석으로는 파형은 된눈떨림이 9명, 시계추눈떨림이 4명이었 다. 방향은 수평눈떨림이 12 명, 수평눈떨림과 회선눈떨림 이 혼합된 환자는 1 명이었다. 이상두위의 방향은 우측 얼굴 돌림이 7명, 좌측 얼굴돌림이 6 명이었다. 1 명에서 얼굴돌림 과 턱올림이 동반되었다. 우측 얼굴돌림에 좌측 머리기울 임이 동반된 환자는 원래의 수술량에 우안 하사근 후전술, 좌안 상사근 힘줄절제술을 추가하여 시행하였다(Table 1). 굴절검사 결과 $1.5 \mathrm{D}$ 이상의 난시가 있는 환자는 5 명이었 고, 근시와 원시의 경우 양안의 구면렌즈대응치가 -3.0 D보 다 큰 환자는 2 명, $+1.0 \mathrm{D}$ 보다 큰 환자는 5 명이었다. 총 6 명
의 환자가 안경을 처방받았으나 안경으로 인한 눈떨림 및 이상두위의 변화는 보이지 않았다.

수술 후 평균 $51.3 \pm 49.60$ 개월(6-183) 동안 추적관찰하 였고, 수술 후 6 개월에 얼굴돌림이 전혀 나타나지 않았던 경우가 5 명, $10^{\circ}$ 이하로 교정된 경우가 7명으로 미용적이거 나 기능적으로 문제가 되지 않는 환자는 총 12 명 $(92.3 \%)$ 이 었다. 추가 수술하지 않은 환자들 중 최종 내원 시 측정한 이상두위 정도에서 얼굴돌림이 전혀 나타나지 않았던 경우 가 4명, $10^{\circ}$ 이하로 교정된 경우가 6 명으로 미용적이거나 기능적으로 문제가 되지 않는 환자는 총 10 명 $(76.9 \%)$ 이었 다. 수술로 과교정된 환자는 3 명 $(23.1 \%)$ 이었지만 얼굴돌림 의 각도는 $10^{\circ}$ 이하로 측정되었다(Table 1). $30^{\circ}$ 이하의 얼 굴돌림이 있는 환자들을 수술하였고, 수술 전 평균 얼굴돌

Table 1. Changes in abnormal head position and strabismus before and after Modified Anderson procedure in patients with nystagmus and abnormal head position

\begin{tabular}{|c|c|c|c|c|c|c|c|c|c|c|}
\hline \multirow{2}{*}{$\begin{array}{r}\text { No. of } \\
\text { cases }\end{array}$} & \multirow{2}{*}{$\begin{array}{c}\text { Sex/age } \\
\text { (years) }\end{array}$} & \multirow{2}{*}{$\begin{array}{l}\text { Wave } \\
\text { form }\end{array}$} & \multirow{2}{*}{$\begin{array}{c}\text { Operation } \\
\text { method: } \\
\text { recession }(\mathrm{mm})\end{array}$} & \multicolumn{3}{|c|}{ Head position } & \multicolumn{3}{|c|}{ Strabismus } & \multirow{2}{*}{$\begin{array}{c}\text { Follow } \\
\text { up } \\
\text { (months) }\end{array}$} \\
\hline & & & & $\begin{array}{l}\text { Preoperative } \\
\text { (face turn) }\end{array}$ & $\begin{array}{c}\text { Postoperative } \\
6 \text { months }\end{array}$ & Final visit & Preoperative & $\begin{array}{l}\text { Postoperative } \\
6 \text { months }\end{array}$ & $\begin{array}{c}\text { Final } \\
\text { visit }\end{array}$ & \\
\hline 1 & $\mathrm{M} / 25$ & $\mathrm{H}(\mathrm{P})$ & $\begin{array}{l}\text { RMR } 10 \\
\text { LLR } 12\end{array}$ & $\mathrm{R} 15$ & Straight & Straight & Ortho & Ortho & Ortho & 6 \\
\hline 2 & $\mathrm{M} / 15$ & $\mathrm{H}(\mathrm{P})$ & $\begin{array}{l}\text { RMR } 10 \\
\text { LLR } 12\end{array}$ & $\mathrm{R} 15$ & Straight & Chin down 15 & Ortho & Ortho & Ortho & 37 \\
\hline 3 & $\mathrm{M} / 5$ & $\mathrm{H}(\mathrm{J})$ & $\begin{array}{l}\text { RMR } 10 \\
\text { LLR } 12\end{array}$ & $\mathrm{R} 15$ & R5 & $\mathrm{L} 10^{*}$ & Ortho & Ortho & Ortho & 183 \\
\hline 4 & $\mathrm{M} / 2$ & $\mathrm{H}(\mathrm{J})$ & $\begin{array}{c}\text { RMR } 10 \\
\text { LLR } 12 \\
\text { /c RIO rec, LSO } \\
\text { tenectomy }\end{array}$ & $\begin{array}{c}\mathrm{R} 20 \\
\text { /c Left tilt }\end{array}$ & R5 & Straight & Ortho & Ortho & Ortho & 25 \\
\hline 5 & $\mathrm{~F} / 11$ & $\mathrm{H}(\mathrm{J})$ & $\begin{array}{l}\text { RMR } 10 \\
\text { LLR } 12 \\
\text { RLR } 4^{\dagger}\end{array}$ & $\mathrm{R} 30$ & R5 & R5 & ET14 & Ortho & Ortho & 6 \\
\hline 6 & $\mathrm{M} / 8$ & $\mathrm{H}(\mathrm{J})$ & $\begin{array}{l}\text { RMR } 10 \\
\text { LLR } 14\end{array}$ & $\begin{array}{c}\mathrm{R} 30 \\
\text { /c chin up } 15\end{array}$ & Straight & Straight & XT12 & XT12 & $\mathrm{X} 12$ & 6 \\
\hline 7 & $\mathrm{M} / 3$ & $\mathrm{H}(\mathrm{J})$ & $\begin{array}{l}\text { RMR } 10 \\
\text { LLR } 12\end{array}$ & $\mathrm{R} 30$ & $\begin{array}{c}\text { R10 } \\
\text { /c chin up } 20\end{array}$ & $\mathrm{R} 15$ & XT8 & Ortho & Ortho & 79 \\
\hline 8 & $\mathrm{M} / 6$ & $\mathrm{H}(\mathrm{J})$ & $\begin{array}{l}\text { LMR } 10 \\
\text { RLR } 12\end{array}$ & L15 & L5 & L5 & Ortho & Ortho & Ortho & 37 \\
\hline 9 & $\mathrm{M} / 10$ & $\mathrm{H}(\mathrm{J})$ & $\begin{array}{l}\text { LMR } 10 \\
\text { RLR } 12\end{array}$ & L20 & L10 & $\mathrm{R} 10^{*}$ & Ortho & Ortho & Ortho & 77 \\
\hline 10 & $\mathrm{M} / 3$ & $\mathrm{H}(\mathrm{P})$ & $\begin{array}{l}\text { LMR } 10 \\
\text { RLR } 12\end{array}$ & L20 & R5 & L10 & XT10 & Ortho & XT12 & 70 \\
\hline 11 & $\mathrm{~F} / 4$ & $\begin{array}{c}\mathrm{H}+\mathrm{T} \\
(\mathrm{P})\end{array}$ & $\begin{array}{l}\text { LMR } 10 \\
\text { RLR } 12\end{array}$ & L25 & L5 & L5 & Ortho & Ortho & Ortho & 89 \\
\hline 12 & $\mathrm{~F} / 9$ & $\mathrm{H}(\mathrm{J})$ & $\begin{array}{l}\text { LMR } 10 \\
\text { RLR } 12\end{array}$ & L25 & Straight & Straight & Ortho & Ortho & Ortho & 11 \\
\hline 13 & $\mathrm{M} / 15$ & $\mathrm{H}(\mathrm{J})$ & $\begin{array}{l}\text { LMR } 13 \\
\text { RLR } 13\end{array}$ & L30 & Straight & $\mathrm{R} 5^{*}$ & XT10 & XT12 & XT10 & 41 \\
\hline
\end{tabular}

The amount of face turn is in degrees.

$\mathrm{M}=$ male; $\mathrm{H}=$ horizontal; $\mathrm{P}=$ pendular; $\mathrm{RMR}=$ right medial rectus; $\mathrm{LLR}=$ left lateral rectus; $\mathrm{R}=$ face turn to right; Ortho = orthophoria; $\mathrm{J}=$ jerk; $\mathrm{L}=$ face turn to left RIO = right inferior oblique; $\mathrm{LSO}=$ left superior oblique; $\mathrm{F}=$ female; $\mathrm{RLR}=$ right lateral rectus; $\mathrm{ET}=$ esotropia; $\mathrm{XT}=$ exotropia; $\mathrm{LMR}=$ left medial rectus; $\mathrm{T}=$ torsional.

*Overcorrected patients; ${ }^{\dagger}$ combined strabismus operation. 
림의 각도는 $22.30 \pm 6.33^{\circ}$ 였고, 수술 후 6 개월째 평균 얼굴 돌림의 각도는 $3.85 \pm 3.63^{\circ}$ 로 교정된 양은 $18.45 \pm 7.18^{\circ}$ 였 다 $(p=0.001$, Table 2). 수술 후 안구운동제한을 나타낸 환자 는 1명으로 우측 얼굴돌림으로 Modified Anderson 술식을 하여 좌안 외직근을 $12 \mathrm{~mm}$ 후전한 결과 좌안 경도의 외전 제한이 나타났으나 이로 인해 사시나 복시 등의 문제를 호 소하지 않았다.

수술 후 이상두위 재발을 보여 추가 수술을 받은 환자는 3 명으로 추가 수술은 평균 $31.3 \pm 5.51$ 개월(26-37)이 경과 한 후 시행하였고, 추가 수술환자에서 1 명은 수술 후 6 개월 에 턱내림의 수직 이상두위가 발생하여 수술 후 31 개월째 양안 상직근 $8 \mathrm{~mm}$ 후전술 시행하였고, 1 명은 수술 후 24 개 월에 얼굴돌림이 재발하여 수술 후 25 개월째 얼굴돌림의 방향과 같은 쪽 안구의 외직근 $8 \mathrm{~mm}$ 절제술, 반대눈 내직 근 $6 \mathrm{~mm}$ 절제술을 시행하였다. 1 명은 수술 전 프리즘 교대 가림검사에서 원거리 10 프리즘디옵터(prism diopters, PD) 외사시에서 수술 후 37 개월에 외사시가 $18 \mathrm{PD}$ 로 증가하여 좌안 외직근 $8 \mathrm{~mm}$ 후전술을 시행하였다. 그 후 15 개월째 얼굴돌림이 재발되어 24 개월째 얼굴돌림의 방향과 같은 쪽 안구의 외직근 $8 \mathrm{~mm}$ 전진술, 반대눈 내직근 $4 \mathrm{~mm}$ 절제술 시행하였다(Table 1).

수술 전 최대교정시력 $(\operatorname{logMAR})$ 으로 좋은 눈은 $0.41 \pm$ 0.17 , 나쁜 눈은 $0.50 \pm 0.17$ 이었고, 수술 후 6 개월째 최대 교정시력으로 좋은 눈은 $0.34 \pm 0.23$, 나쁜 눈은 $0.45 \pm$ 0.25 였다. 수술 전과 비교하여 수술 후 6 개월째 최대교정시 력은 시력이 좋은 눈과 나쁜 눈, 모두에서 호전을 보였지만 통계적으로 유의하지는 않았다(각 $p=0.068, p=0.228$, Table 2).

\section{고 찰}

본 연구에서는 13 명의 $30^{\circ}$ 이내의 얼굴돌림을 보인 영아 눈떨림환자에서 Modified Anderson 술식 후 최소 6개월, 최대 15 년 기간의 수술 효과를 평가하였다. 수술 후에 얼굴 돌림이 $10^{\circ}$ 이내인 환자는 수술 6 개월 후 $92.3 \%$, 최종 추적
관찰 시에는 $76.9 \%$ 로 우수한 결과를 얻을 수 있었다. 1953년 $\mathrm{Kestenbaum}^{2}$ 은 영아눈떨림에 동반된 이상두위를 교정하는 수술을 최초로 소개하였다. 정지점을 제 1 안위로 옮기기 위 해 정지점이 있는 쪽으로 작용하는 수평직근을 후전시키고, 반대방향으로 작용하는 수평직근을 절제하였다. 1973년 $\mathrm{Parks}^{3}$ 는 Kestenbaum 술식에서 두 눈을 동시에 수술하면서 얼굴돌림의 방향과 같은 쪽 안구의 내직근 $5 \mathrm{~mm}$ 후전술과 외직근 $8 \mathrm{~mm}$ 절제술을 하였고, 반대눈은 외직근 $7 \mathrm{~mm}$ 후 전술과 내직근 $6 \mathrm{~mm}$ 절제술을 하여 각 눈의 수술량이 $13 \mathrm{~mm}$ 되도록 하는 5-6-7-8 mm의 Modified Kestenbaum 술식을 소개하였다. 그러나 $30^{\circ}$ 이상으로 얼굴돌림이 큰 경우에는 부족교정이 되거나 재발이 많이 일어나 1973년 Calhoun and Harley ${ }^{4}$ 는 Augmented Kestenbaum 술식을 제안하였고, 1984년 Nelson et $\mathrm{al}^{5}$ 과 1987년 Mitchell et $\mathrm{al}^{8}$ 은 기존의 수 술법에 수술량을 증량시킨 수술법을 소개하였고, 1987년 Taylor and Jesse ${ }^{9}$ 는 Modified Kestenbaum 술식에 Anderson 술식을 참고하여 얼굴돌림 반대 방향의 저속기 근육을 선 택적으로 약화시키기 위해 양안의 절제량보다 후전량이 더 많은 Modified Anderson-Kestenbaum 술식을 소개하였다.

일정한 정지점을 가지고 있지 않고 이상두위의 방향이 바뀌는 선천주기교대눈떨림의 경우 1960 년 $\mathrm{Bietti}^{10}$ 가 4 개 의 수평직근을 크게 후전하여 수평직근의 힘을 약화시켜 눈떨림 자체를 감소시킬 수 있다고 제시하였다. von Noorden and Sprunger ${ }^{11}$ 은 4 개의 수평직근을 근부착점으로부터 $10 \mathrm{~mm}$ 후방으로 후전하였으며, Helveston et $\mathrm{al}^{12}$ 은 양안을 각막 윤 부로부터 내직근을 $11.5 \mathrm{~mm}$ 후전, 외직근은 $13 \mathrm{~mm}$ 후전 하였다. 4 개의 수평직근을 후전하는 것은 약간의 내전 제한 을 야기시켰지만 유의할 정도의 안구운동제한은 아니었고 진폭과 빈도를 감소시킬 뿐 아니라 시력, 이상두위는 대다 수에서 호전되었다. Hertle et $\mathrm{al}^{13}$ 은 영아눈떨림과 눈피부백 색증환자에서 4 개의 수평직근을 후전 및 절제하는 외안근 수술을 시행하였고 수술 후 3 개월째 1명을 제외한 14명에 서 시력호전이 있었음을 보고하였고, 수술 후 12 개월째 중심와 시간이 유의하게 늘어났음을 보고하였다. 2002년

Table 2. Changes in the clinical characteristics after Modified Anderson procedure in patients with nystagmus and abnormal head position

\begin{tabular}{|c|c|c|c|c|c|c|c|}
\hline & \multirow{2}{*}{ Preoperative } & \multicolumn{6}{|c|}{ Postoperative } \\
\hline & & 1 week & $p$-value ${ }^{*}$ & 6 months & $p$-value ${ }^{*}$ & Final visit & $p$-value \\
\hline Face turn $\left({ }^{\circ}\right)$ & $22.30 \pm 2.30$ & $1.36 \pm 2.34$ & 0.003 & $3.85 \pm 0.85$ & 0.001 & $6.15 \pm 5.46$ & 0.002 \\
\hline \multicolumn{8}{|c|}{ Visual acuity (logMAR) } \\
\hline Better eye & $0.41 \pm 0.17$ & $0.44 \pm 0.19$ & 0.490 & $0.34 \pm 0.23$ & 0.068 & $0.26 \pm 0.21$ & 0.008 \\
\hline Worse eye & $0.50 \pm 0.17$ & $0.54 \pm 0.23$ & 0.496 & $0.45 \pm 0.25$ & 0.228 & $0.35 \pm 0.20$ & 0.050 \\
\hline
\end{tabular}

Values are presented as mean \pm standard deviation unless otherwise indicated.

*Wilcoxon signed rank test, which compared preoperative and postoperative data. 
Arroyo-Yllanes et $\mathrm{al}^{7}$ 은 영아눈떨림에 동반된 이상두위교정 술로 Augmented Anderson 술식의 효과를 보고하였다. 이 들은 이상두위를 일으키는 수평직근의 동향근을 후적도부 로 $2 \mathrm{~mm}$ 후전하는 술식을 시행하였는데, 해부학적 적도부 인지 기능적 적도부인지 명확하게 명시하지 않은 문제가 있었다. Gupta et $\mathrm{al}^{14}$ 은 정지점에서의 얼굴돌림에 따라 수 평직근 동향근을 각각 수술하였는데, 얼굴돌림 방향과 같 은 쪽 안구의 내직근을 $9 \mathrm{~mm}$ 후전, 반대 눈 외직근은 $12 \mathrm{~mm}$ 후전하였다. 기능적 적도부가 비측은 해부학적 적도부보다 $2 \mathrm{~mm}$ 앞에 있고 이측은 해부학적 적도부보다 $2 \mathrm{~mm}$ 뒤에 있기에 내직근보다 외직근을 더 많이 후전하는 것이 해부 학적으로 적절한 술식이었다. 본 연구에서 시행한 Modified Anderson 술식은 이전 연구보다 후전량을 늘려 내직근 10-13 mm 후전술, 외직근 12-14 mm 후전술을 적용하였다. 본 연구에서 수술 전 평균 얼굴돌림의 각도는 $22.30 \pm 6.33^{\circ}$ 였고 수술 후 6 개월째 평균 얼굴돌림의 각도는 $3.85 \pm 3.63^{\circ}$ 로 교정된 양은 $18.45 \pm 7.18^{\circ}$ 였는데, Hertle et $\mathrm{al}^{13}$ 은 4 개의 수평직근을 후전 및 절제하는 외안근수술을 시행하였고 수 술 전 평균 얼굴돌림 각도 $25.6^{\circ}$ 에서 수술 후 3 개월째 5.1 $\pm 8.7^{\circ}$ 로 교정된 양이 $20.1^{\circ}$ 임을 보고하였고, Gupta et $\mathrm{al}^{14}$ 은 수술 전 평균 얼굴돌림 각도 $32.5 \pm 5.8^{\circ}$ 에서 수술 후 3 개 월째 평균 얼굴돌림 각도 $5.0 \pm 8.7^{\circ}$ 로 교정된 양이 $27.5^{\circ}$ 였 음을 보고하였다. Kumar et $\mathrm{al}^{15}$ 은 Anderson-Kestenbaum 술식을 시행한 군과 Modified Anderson 술식에 수평직근 건절제술을 병행한 군과 병행하지 않은 군 총 3 가지 환자 군을 비교하였고, 수술 후 1 개월째 모두 유의한 시력개선을 보였으며, 각각을 비교하였을 때 유의한 차이는 보이지 않 았다. 그리고 이상두위교정의 정도는 수술 전 평균 얼굴돌 림 각도 $20.89^{\circ}$ 에서 수술 후 $3.21^{\circ}$ 로 유의하게 교정되었다. 앞선 연구와 비교하여 본 연구에서는 교정량이 상대적으로 적었으나, 4 개의 수평직근을 후전 및 절제하는 수술과 Modified Anderson 술식에 건절제술을 병행한 수술을 비교 하면 2개의 근육을 수술하는 Modified Anderson 술식만으 로 이상두위교정에 효과적인 것을 알 수 있었다.

두 개의 수평근후전술은 Modified Kestenbaum 술식이나 두 눈의 수평 네 개 직근을 모두 후전하는 방법과 비교하였 을 때, 술식 자체가 간단하고 수술하는 수평직근의 수가 적 다. 그리고 오직 후전술만 하기 때문에 수술량을 조절할 때 가역성이 뛰어나다. ${ }^{14}$ 또한 Modified Anderson 술식 후 이 상두위가 재발한 경우에 첫 수술 때 절제하지 않았던 급속 기의 근육을 절제하면 되는 장점이 있다. 이전 연구에서 많 은 양의 후전과 절제를 할 경우 중등도의 안구운동제한이 관 찰되었다고 보고하였다. ${ }^{5,16}$ 반면, von Noorden and Sprunger ${ }^{11}$ 은 많은 양의 후전을 하여도 경도의 안구운동제한만 발생
하였다고 보고하였다. 이는 후전 시 근육 부착점이 해부학 적 적도부 뒤에 위치하여 근육과 안구가 여전히 붙어있고 수축 시 회전력을 나타낼 수 있기 때문이다. 두 눈의 수평 네 개 직근을 모두 후전하는 방법에서 내직근 6-7 mm 후 전, 외직근 9-10 $\mathrm{mm}$ 후전하는 정도의 augmented recession 을 한 결과 안구운동제한이 발생하였지만 이상두위 해결 자체에는 큰 문제가 되지 않았다. ${ }^{9}$ 두 개의 수평근후전술로 두 눈의 수평 네 개 직근을 모두 후전하는 방법과 같은 정 도의 이상두위교정 효과를 나타내려면 훨씬 많은 양의 후 전량이 필요하다. Gupta et $\mathrm{al}^{14}$ 는 Modified Anderson 술식 을 시행받은 환자 12 명 중 8 명에서 경도의 안구운동제한이 있었다고 보고하였다. 또한 Arroyo-Yllanes et $\mathrm{al}^{7}$ 도 비슷한 결과를 보였다. 본 연구에서 많은 양의 후전을 하였지만 Modified Anderson 술식 후 6개월째 경도의 외전장애가 나 타난 환자는 1 명이었고 이러한 안구운동 이상이 이차적인 문제를 야기하지 않았고, 미용적이나 기능적으로 이상이 없었다.

수평직근의 과도한 후전 시에 안구운동제한뿐만 아니라 사시 정도가 증가할 수 있는데, 본 연구에서도 1 명에서 수 술 후 37 개월째 외사시가 수술 전보다 증가되어 사시교정 술을 시행받았다. 많은 양의 후전을 하여도 안구운동제한 이나 사시각 증가가 임상적으로 의미 있지 않았다.

본 연구의 제한점으로는 첫째, 얼굴돌림 정도에 따라 Modified Anderson 술식의 수술량 정도를 다르게 했으나, 정도에 따라 동일한 양을 증량하지 않았다는 점이다. 둘째, 후향적인 연구로 수술 전 제 1 안위와 정지점에서의 시력을 구분하지 않았다.

$30^{\circ}$ 이내의 얼굴돌림을 보인 영아눈떨림환자에서 Modified Anderson 술식을 시행한 결과 이전 다른 연구들의 술식과 비교하여 비슷한 이상두위교정의 효과가 있음을 알 수 있 었다. 따라서 수술하는 근육 개수가 적고 수술자가 수술하 기에 용이한 Modified Anderson 술식을 영아눈떨림으로 인 한 얼굴돌림수술에 적극 고려해볼 수 있을 것으로 생각된 다. 그러나 장기간 수술 효과에 대한 전향적 연구가 추가되 어야 할 것으로 생각된다.

\section{REFERENCES}

1) Dell'Osso L. Congenital, latent and manifest latent nystagmus--similarities, differences and relation to strabismus. Jap J Ophthalmol 1985;29:351-68.

2) Kestenbaum A. New operation for nystagmus. Bull Soc Ophtalmol Fr 1953;6:599-602

3) Parks MM. Congenital nystagmus surgery. Am Orthop J 1973;23:35-9.

4) Calhoun J, Harley R. Surgery for abnormal head position in congenital nystagmus. Trans Am Ophthalmol Soc 1973;71:70-83; dis- 
cussion 84-7.

5) Nelson LB, Ervin-Mulvey LD, Calhoun JH, et al. Surgical management for abnormal head position in nystagmus: the augmented modified Kestenbaum procedure. Br J Ophthalmol 1984;68:796-800.

6) Anderson JR. Causes and treatment of congenital eccentric nystagmus. Br J Ophthalmol 1953;37:267-81.

7) Arroyo-Yllanes M, Fonte-Vázquez A, Pérez-Pérez J. Modified Anderson procedure for correcting abnormal mixed head position in nystagmus. Br J Ophthalmol 2002;86:267-9.

8) Mitchell PR, Wheeler MB, Parks MM, et al. Kestenbaum surgical procedure for torticollis secondary to congenital nystagmus. J Pediatr Ophthalmol Strabismus 1987;24:87-93.

9) Taylor JN, Jesse K. Surgical management of congenital nystagmus. Aust NZ J Ophthalmol 1987;15:25-34.

10) Bietti G. Traitement medicochirurgical du nystagmus. L'Annee Ther Clin Ophthalmol 1960;11:268-93.

11) von Noorden GK, Sprunger DT. Large rectus muscle recessions for the treatment of congenital nystagmus. Arch Ophthalmol 1991;
109:221-4.

12) Helveston EM, Ellis FD, Plager DA. Large recession of the horizontal recti for treatment of nystagmus. Ophthalmology 1991;98: 1302-5.

13) Hertle RW, Anninger W, Yang D, et al. Effects of extraocular muscle surgery on 15 patients with oculo-cutaneous albinism (OCA) and infantile nystagmus syndrome (INS). Am J Ophthalmol 2004; 138:978-87.

14) Gupta R, Sharma P, Menon V. A prospective clinical evaluation of augmented Anderson procedure for idiopathic infantile nystagmus. J AAPOS 2006;10:312-7.

15) Kumar A, Shetty S, Vijayalakshmi P, Hertle RW. Improvement in visual acuity following surgery for correction of head posture in infantile nystagmus syndrome. J Pediatr Ophthalmol Strabismus 2011;48:341-6.

16) Pratt-Johnson J. Results of surgery to modify the null-zone position in congenital nystagmus. Can J Ophthalmol 1991;26:219-23.

\section{$=$ 국문초록 $=$}

\section{$30^{\circ}$ 이내의 얼굴돌림을 보인 영아눈떨림환자에서 Modified Anderson 술식}

목적: $30^{\circ}$ 이내의 얼굴돌림을 보인 영아눈떨림환자에서 Modified Anderson 술식의 효과를 알아보고자 하였다.

대상과 방법: 2002년 2월에서 2017년 3월까지 부산대학교병원에서 영아눈떨림으로 진단받고 이상두위교정을 위해 Modified Anderson 술식을 시행받은 13 명의 의무기록을 통해 수술 전후 1 주, 6 개월, 최종 내원 시 최대교정시력, 굴절검사, 이상두위 정도, 안구운동 및 사시각을 비교하였다. 수술은 얼굴돌림에 따라 저속기에 해당하는 동향근인 2 개의 수평직근을 후전시키는 술식(한눈 내직근 $10 \mathrm{~mm}$ 후전술, 반대눈 외직근 $12 \mathrm{~mm}$ 후전술)을 시행하였다.

결과: 대상 환자들의 평균 수술나이는 8.9세(2-25)였고, 수술 후 평균 51.3개월(6-183)의 추적 결과 수술 후 6개월에 얼굴돌림이 전혀 없거나 $10^{\circ}$ 이하로 교정된 경우가 12 명(92.3\%)이었고, 3명(23.1\%)에서 추가 수술을 하였다. 수술 전 평균 얼굴돌림의 각도는 22.30였 고, 수술 후 6 개월째 얼굴돌림의 각도는 $3.85^{\circ}$ 로 유의한 호전을 보였다 $(p=0.001)$. 최대교정시력(logMAR)으로 수술 전 좋은 눈은 0.41 , 나쁜 눈은 0.50 이었고, 수술 후 6 개월째 좋은 눈은 0.34 , 나쁜 눈은 0.45 로 각각 호전을 보였다 $(p=0.068, p=0.228)$. 많은 양의 후전술 을 시행하였음에도 불구하고, 경도의 외전장애를 나타낸 환자는 1명이었다.

결론: $30^{\circ}$ 이내의 얼굴돌림을 보인 영아눈떨림환자에서 이상두위는 Modified Anderson 술식으로 효과적으로 교정할 수 있었고, 과교 정되지 않았다.

〈대한안과학회지 2019;60(6):569-574〉

양상철 / Sang Cheol Yang 부산대학교 의과대학 안과학교실 Department of Ophthalmology, Pusan National University School of Medicine

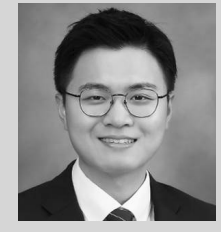

